\title{
CORPORATE SOCIAL RESPONSIBILITY (CSR) IN INDIAN CONTEXT- AN ANALYSIS OF RELEVANT PROVISIONS OF THE COMPANIES' ACT, INTERNATIONAL AND NATIONAL INSTRUMENTS, THEORIES AND MODELS
}

\author{
Ravi Raj Atrey \\ PhD Scholar, School of Social Work, \\ Indira Gandhi national Open University, New Delhi
}

DOI: 10.46609/IJSSER.2020.v05i07.007 URL: https://doi.org/10.46609/IJSSER.2020.v05i07.007

\begin{abstract}
This paper is based on the analysis of different theories and models of CSR prevailing around the Globe and their relevance in Indian context. An analysis of the CSR ecosystem in the country with impacts of the regulatory and promotional provisions mentioned under the Companies Act 2013, suggestive fields of CSR given under the Schedule VII of the Companies Act 2013 and CSR Rules 2014 as well as different ordinance and notifications issued by the Government of India and various State Governments has also been presented. Influence of various international and national voluntary guidelines, codes and standards i.e. ISO 26000, UNGC, AccountAbility, OECD Guidelines, GRI, National Voluntary Guidelines on Economic, Social and Environmental Responsibilities of the Business on the CSR planning and implementation and their linkages with the CSR related provisions of the Companies Act 2013 has been explored. How above regulatory and voluntary ecosystem affects CSR projects of companies in India has also been explored and presented in this paper. As a result of the above analysis, the researcher has presented a newly developed model on CSR in Indian context.
\end{abstract}

Keywords: Corporate Social Responsibility, Models of CSR, Sustainable development, Corporate Social Performance

\section{INTRODUCTION}

The fourth industrial revolution or Industry 4.0 and perspectives on Corporate Social Responsibility (CSR) attract our attention towards responsible business practices, as CSR is one of the ways to adopt and integrate responsible behaviours of industries towards social, economic and environmental aspects of their existence. 
International Journal of Social Science and Economic Research

ISSN: $2455-8834$

Volume: 05, Issue: 07 "July 2020"

'CSR in India versus CSR in rest of the world' has been a subject of debate. Till now two key players were observed in the sphere of social development - a) Government; and b) NGOs/ International / Inter-governmental organizations. One of the most significant contributions of introducing mandatory provisions related to Corporate Social Responsibility in the Companies Act, 2013 in India is the emergence of corporate sector as third pillar of social development in India.

This paper was written based on the analysis of secondary information on corporate social responsibility eco-system in India and Internationally. It starts with providing conceptual understanding and different definitions on the Corporate Social Responsibility; provides expenditure trends analysis in India as per records of the Government; analysis of legal paradigm of CSR in India including relevant provisions of the Companies Act, 2013, Corporate Social Responsibility Rules 2014,National Guidelines for Responsible Business Conduct, and an analysis of the Companies (Amendment) Act, 2019; this paper also presents the international eco-system on CSR by analysing relevant International Standards, Codes and Guidelines; theories and models on CSR have been analysed and a new model has been proposed.

\section{DEFINITIONS OF CORPORATE SOCIAL RESPONSIBILITY}

\section{CSR Definition as per the Companies Act, 2013}

'Corporate Social Responsibility (CSR) means and includes but is not limited to:-

(i) Projects or programmes relating to activities specified in Schedule VII to the Act; or

(ii) Projects or programmes relating to activities undertaken by the board of directors of a company (Board) in pursuance of recommendations of the CSR Committee of the Board as per declared CSR Policy of the company subject to the condition that such policy will cover subjects enumerated in Schedule VII of the Act'.

\section{European Union}

'CSR is a concept whereby companies integrate social and environmental concerns in their business operations and in their interaction with their stakeholders on a voluntary basis'. (European Union Commission, 2001)

\section{ISO 26000}

The responsibility of an organisation for the impacts of its decision and activities on society and the environment, through transparency and ethical behaviour that:

- Contribute to sustainable development, including health and welfare of society

- Takes into account the expectation of stakeholders 


\section{International Journal of Social Science and Economic Research}

ISSN: $2455-8834$

Volume: 05, Issue: 07 "July 2020"

- Is in compliance with applicable law and consistent with international norms of behaviour

- Is integrated throughout the organisation and practices in its relationship

This implies the willing inclusion by business of social and environmental concerns in the commercial (economic) activities and their relation with their stakeholders. CSR Correlates with the social and environmental dimensions of Sustainable Development as defined by Brundtland and the model of the triple bottom line (Economic-Environment-Social or Profit-Planet-People). CSR may be considered as a tool, way of doing business towards sustainable development.CSR is a good way of doing business strategically and profitably.

(Atrey, ISO:26000 - Theory and Practice , 2012)

\section{Millennium Survey on the CSR}

According to the millennium survey on CSR conducted in year 2000, various countries analyse CSR from different perspectives. Australian perspective is that mostly the responsibility of the companies is to contribute social and environmental values, whereas China's perspective is that social responsibility is more to do with creating jobs and paying taxes and being a good economic agent in society. Social and environmental value creation or being a corporate citizen to create an economic value was another aspect. (The Millennium Poll on Corporate Social Responsibility, Global Public Opinion on the Changing Role of Companies, 1999).

\section{Legal \& Regulatory Paradigm}

Government of India has introduced special sections in the Companies Act, 2013 by which it is now mandatory for the corporates having annual net worth of INR 500 Crore or more, net profit of INR 5 Crore or more, or turnover of INR 1000 Crore or more, to spent $2 \%$ of their net average profit (after tax) in last three consecutive years on the corporate social responsibility initiatives. Government of India has also introduced Schedule-VII in the Companies Act, 2013 detailing about the suggestive activities to be taken by the corporations under the CSR.

\section{Section 135 of the Companies Act, 2013}

Section 135 of the Companies Act, 2013 deals with the Corporate Social Responsibility. The provisions given in the Act under this section are as under:

- Every company having net worth of rupees five hundred crore or more, or turnover of rupees one thousand crore or more or a net profit of rupees five crore or more during any financial year shall constitute a Corporate Social Responsibility Committee of the Board 


\section{International Journal of Social Science and Economic Research}

ISSN: $2455-8834$

Volume: 05, Issue: 07 "July 2020"

consisting of three or more directors, out of which at least one director shall be an independent director.

- The Board's report under sub-section (3) of Section 134 shall disclose the composition of the Corporate Social Responsibility Committee.

- The Corporate Social Responsibility Committee shall:

a) Formulate and recommend to the Board, a Corporate Social Responsibility Policy which shall indicate the activities to be undertaken by the company as specified in Schedule VII;

b) Recommend the amount of expenditure to be incurred on the activities referred to in clause $(a)$; and

c) Monitor the Corporate Social Responsibility Policy of the company from time to time.

- The Board of every company referred to in sub-section (l) shall:

a) After taking into account the recommendations made by the Corporate Social Responsibility Committee, approve the Corporate Social Responsibility Policy for the company and disclose contents of such Policy in its report and also place it on the company's website, if any, in such manner as may be prescribed; and

b) Ensure that the activities as are included in Corporate Social Responsibility Policy of the company are undertaken by the company.

- The Board of every company referred to in sub-section (1), shall ensure that the company spends, in every financial year, at least two per cent of the average net profits of the company made during the three immediately preceding financial years, in pursuance of its Corporate Social Responsibility Policy:

Provided that the company shall give preference to the local area and areas around it where it operates, for spending the amount earmarked for Corporate Social Responsibility activities. Provided further that if the company fails to spend such amount, the Board shall, in its report made under clause (o) of sub-section (3) of section 134, specify the reasons for not spending the amount.

Explanation: For the purposes of this section "average net profit" shall be calculated in accordance with the provisions of Section 198.

There have been time to time amendments in the Section 135 and the Schedule VII of the Companies Act.

\section{Corporate Social Responsibility Rules}

Government of India, vide Gazette Notification dated 27.02.2014 made rules in exercise of the powers conferred under the Section 135 and sub-sections (1) \& (2) of the Section 469 of the Companies Act, 2013. These rules are known as the Companies (Corporate Social Responsibility) Rules, 2014. Further, on 23.05.2016 Ministry of Corporate Affairs notified Companies (Corporate Social Responsibility) Amendment Rules, 2016. These rules explain 
activities enlisted under the schedule VII, composition and functions of CSR Committee, formulation process and pre-requisites of CSR Policy and CSR reporting and disclosure among others.

\section{National Voluntary Guidelines on Social, Environmental and Economic Responsibilities of Business}

There are nine key principles of National Voluntary Guidelines on Social, Environmental and Economic Responsibilities of Business:

i. Principle 1: Businesses should conduct and govern themselves with ethics, transparency and accountability.

ii. Principle 2: Businesses should provide goods and services that are safe and contribute to sustainability throughout their life cycle.

iii. Principle 3: Businesses should promote the wellbeing of all employees.

iv. Principle 4: Businesses should respect the interests of, and be responsive towards all stakeholders, especially those who are disadvantaged, vulnerable and marginalised.

v. Principle 5: Businesses should respect and promote human rights.

vi. Principle 6: Business should respect, protect, and make efforts to restore the environment.

vii. Principle 7: Businesses, when engaged in influencing public and regulatory policy, should do so in a responsible manner.

viii. Principle 8: Businesses should support inclusive growth and equitable development.

ix. Principle 9: Businesses should engage with and provide value to their customers and consumers in a responsible manner.

(Ministry of Corporate Affairs, Government of India, 2011)

\section{National Guidelines on Responsible Business Conduct:}

The responsible business practice is a continuous process in which the corporations integrate the responsible behaviour at each step and activity of the business. Starting from the sourcing, procurement, manufacturing, supplying, etc. the ethical behaviour of the firms towards natural resources should be the part and parcel of each of their activities. Socially responsible behaviour is also an integral part of it.

Government of India launched National Voluntary Guidelines on Economic, Social and Environmental Responsibilities of Business in 2007 which were revised in 2009 and 2011. The next revision was introduced as the National Guidelines on Responsible Business Conduct of Business, replacing the earlier guidelines. (Ministry of Corporate Affairs, Govt. of India, 2018) 
International Journal of Social Science and Economic Research

ISSN: $2455-8834$

Volume: 05, Issue: 07 "July 2020"

\section{The Companies (Amendment) Act, 2019}

Government of India introduced a Bill to amend the Companies Act to restructure provisions about unspent funds for CSR and impose penalty and criminal action on firms and officials not adhering to these provisions. Accordingly, the Companies (Amendment) Act, 2019 came into force.The Companies (Amendment) Act, 2019came into effect on July 31, 2019 vide Gazette Notification No. 22 of 2019 and replaced the Companies (Amendment) Second Ordinance, $\underline{2019}$ with certain additional amendments. Companies operating in India falling under the criteria of CSR, now need to consider the changes brought through the Companies Amendment Act, 2019. Below are the highlights of some of the key provisions of the Act:

\section{Corporate Social Responsibility (CSR) spending}

The Act mandates that companies with a profit of more than INR 5 crore, turnover of INR 100 crore, and net worth of more than INR 500 crore have to spend at least two percent of their three years' annual average net profit towards CSR activities.

Further, companies are now obliged to transfer their unspent CSR funds to one of the funds prescribed under Schedule VII of the Act (such as the Prime Minister Relief Fund) within six months of the end of the financial year and disclose the reasons for non-spending in their annual report.

If the CSR funds are committed to certain ongoing projects, the company must transfer the amount to an unspent account with a scheduled bank within 30 days from the end of the financial year. From here, the amount must be utilized for those projects within three years. If the company fails to spend this amount, it must transfer it to one of the funds mentioned in Schedule VII of the Act.

In case of any violation of the CSR provisions, the company is liable to a minimum penalty fee of INR 0.5 lakh which may extend to INR 25 lakh. Further, every defaulting officer of the company may be liable to imprisonment for up to three years, or a fine up to INR 5 lakh or both.

\section{Stricter CSR - Imprisonment upto three years}

The CSR amendments introduced under the Act now require companies to deposit the unspent CSR funds into a fund prescribed under Schedule VII of the Act within the end of the fiscal year. This amount must be utilized within three years from the date of transfer, failing which the fund must be deposited in to one of the specified funds. 
International Journal of Social Science and Economic Research

ISSN: $2455-8834$

Volume: 05, Issue: 07 "July 2020"

The new law prescribes for a monetary penalty as well as imprisonment in case of non-compliance. The penalty ranges from INR 50,000 to INR 25 lakh whereas the defaulting officer of the company may be liable to imprisonment for up to three years, or a fine up to INR 5 lakh, or both.

\section{Clarification by Government on imprisonment provision}

Allaying industry concerns, Finance and Corporate Affairs Minister after amendments in the Companies Act, expressed that violations of CSR norms under the companies law will be treated only as civil liability and not as a criminal offence (confirmed in media reports). After expression of concerns over penal provisions for non-compliance with Corporate Social Responsibility (CSR) requirements in the amended Companies Act, 2013, the Ministry of Corporate Affairs plans to review the sections concerned under the Companies Act.

Finance and Corporate Affairs Minister has also assured the industry that the government will review the criminal penal provisions on Corporate Social Responsibility contained in the recent amendments to the Companies Act.

It has also been conveyed that CSR notices with retrospective effect "were unacceptable" and that a stop may be putted to them. Amendments to the Companies Act have empowered the government to put the officers concerned in jail for up to three years, besides imposing monetary fines if they do not adhere to CSR norms. After the new amendments, firms will have to spend on CSR, and the earlier practice of explaining to shareholders about not doing so has been discontinued.

\section{High Level Committee on CSR}

A High level committee on Corporate Social Responsibility was constituted in October, 2018 in Ministry of Corporate Affairs, it has among its members N Chandrasekaran, Chairman, Tata Sons, and Amit Chandra, Managing Director, Bain Capital Private Equity, among others. It is headed by Injeti Srinivas, Secretary, Ministry of Corporate Affairs, Government of India. Barely a week after Finance Minister's assurance to corporate entities to review the jail-term provision in the corporate social responsibility (CSR) law, this high-level committee also recommended that non-compliance with CSR norms be made a civil offence and moved to a penalty regime. This is a departure from the recent policy change which had provided for a three-year jail term for violating CSR norms. The committee chaired by Injeti Srinivas, Secretary, Ministry of Corporate Affairs, Govt. of India, submitted its recommendations to Hon'ble Minister of Corporate Affairs, suggesting that CSR expenditure be made tax deductible, in order to 


\section{International Journal of Social Science and Economic Research}

ISSN: $2455-8834$

Volume: 05, Issue: 07 "July 2020"

incentivise CSR spending by companies. The committee also suggested that there is a need to address the distortions in CSR spending arising from prevalent tax structure. It has also suggested a provision to carry forward unspent CSR balance for three to five years. (media report)

It has been conveyed that a clarification may be issued that for newly incorporated companies the CSR obligation under Section 135 of the Companies Act "shall lie only after they have been in existence for three years", the committee said in its report. The committee has also said that CSR should not be used as a "means of resource-gap funding for government schemes". According to the new CSR norms under Section 135 of the Companies Act a company has to earmark a part of its profit for social activities and transfer all unspent amount to an escrow account if it is an ongoing project. This account will be opened by the company concerned in a bank and be called the unspent corporate social responsibility account. The CSR expenditure which remains unspent in three years would be transferred to any fund specified in Schedule VII of the Companies Act such as the Swachch Bharat Kosh, the Clean Ganga Fund, and the Prime Minister's Relief Fund. The central government funds should be discontinued as CSR spend, the committee report said and instead a special designated fund should be created for transfer of unspent CSR money beyond three to five years.

The committee has recommended that Schedule VII be aligned with the Sustainable Development Goals (SDGs) to include sports promotion, senior citizens' welfare, welfare of differently abled persons, disaster management, and heritage protection. The idea behind this is to ensure that the CSR amount should be spent by the company — "it must not be lying with the company."

According to the Government data of the total 21,337 companies liable for CSR 9,753 companies did not report CSR activity in 2017-18. The panel has emphasised that CSR spending has to be a "board-driven process to provide innovative technology-based solutions for social problems" and that the board has to assess the credibility of an implementation agency, which have to be registered with the Ministry of Corporate Affairs to carry out CSR activities.

It has also suggested third-party assessment of major CSR projects and bringing CSR under the purview of statutory financial audit. CSR spending will have to become part of the financial statements of the company. The committee has also suggested that companies having CSR prescribed amount below Rs. 50 lakh may be exempted from constituting a CSR committee. It was recommended by the panel that Government may identify 5\% of the CSR mandated companies on a random basis for third-party assessments. The other recommendations of the committee include developing a CSR exchange portal to connect contributors, beneficiaries and 
International Journal of Social Science and Economic Research

ISSN: $2455-8834$

Volume: 05, Issue: 07 "July 2020"

agencies, allowing CSR in social benefit bonds and promoting social impact companies. (Ministry of Corporate Affairs, Govt. of India, 2019)

\section{International Standards / Codes / Guidelines}

Role of International instruments viz. Standards, Codes and Guidelines in the CSR eco-system in vital. Multi-national companies tend to adopt such instrument to universalize their processes and actions. Some of the important instruments are presented below in brief:

\section{Organisation for Economic Cooperation and Development (OECD) Guidelines}

Organisation for Economic Cooperation and Development (OECD) released guidelines in the form of Code of Conduct for the Multinational Companies in year 1976 as an Annexure to the non-binding OECD Deceleration and Decision on International Investment and Multinational Enterprises. These guidelines were recommended by the participating Governments as voluntary guidelines. Particularly with regard to the responsible behaviour of the companies, these guidelines talk about Transparency/Disclosures, Employment and Industrial Relations, Environment Protection, Combating Bribery, and Consumers' interests. The guidelines were amended in the years 1979, 1984, 1991 and in 2000. (Organization for Economic Cooperation and Development, 2008)

\section{Caux Roundtable Principles}

In 1994, to promote collaborations among the Japanese, American and the European business leaders, during the Caux Round Table it was agreed that apart from rules, systems and policies for the business are necessary to obtain the trust of the society. They play a constructive role in resolving trade frictions but the most basic requirement is that the corporations act responsibly. Accordingly, the Caux Round Table Principles for Business were agreed. The Caux Principles were based upon the three phenomena of the participating regions:

a) The Japanese concept of 'Kyosie': Kyosie represents the idea of living and working together for the common good, enabling cooperation and mutual prosperity to coexist with healthy and fair competition;

b) The American concept of 'Minnesota': Minnesota principles are the American guidelines on fair corporate behaviour;

c) The European concept of 'Human Dignity': The European concept of human dignity says that the inviolable principle of human dignity of each person to be respected by the Corporations while they pursue their profit-making activities. 
Based on the above concepts, the following seven principles were adopted with the hope that these will serve as a reference not only for the participating countries but will also be used in other developing countries around the globe where member countries' companies are operating:

i. Responsibilities of the Business to be beyond shareholders and towards stakeholders

ii. The economic and social impact of business towards innovation, justice, and world community

iii. Business behaviour to be beyond Letter of Law and towards a Spirit of Trust

iv. Respect for Rules

v. Support for Multilateral Trade

vi. Respect for the Environment

vii. Avoidance of the illicit operations

(cauxroundtable.org, 2010)

\section{Social Account Ability 8000 Standard}

The organisation called 'Social Accountability International' released first International Standard on Human Rights and Ethical Behaviour called 'Social Accountability 8000' in year 1997. This standard came into the existence to mainly tackle various issues related to unfair labour practices. (Social Accountability International, 2001)

\section{Account Ability 1000 Standard}

Institute of Social and Ethical Accountability in year 1999 released Account Ability 1000 standard for ensuring social and ethical accountability and high quality auditing and reporting practices, it ensures the accountability for stakeholders in terms of governance structure, human rights, community development, and environmental protection, etc. (AA1000 Stakeholder Engagement Standard, 2015)

\section{Ethics Compliance Standard 2000}

The Reitaku Centre for Economic Studies, Reitaku University released the 'Ethics Compliance Standard 2000' in year 1999. It was well accepted around the world that companies must behave ethically and comply with social norms. But the systems to address CSR issues were lacking in the existence. The Ethics Compliance Standard 2000 fulfilled the need by providing direction that systems should take to ensure compliance with ethical standards, laws and regulations. (Reitaku University Business Ethiics and Compliance Research Centre, 2007)

\section{Green Paper 366}


International Journal of Social Science and Economic Research

ISSN: $2455-8834$

Volume: 05, Issue: 07 "July 2020"

The Gyllenhammar Report was released in the year 1998 advocating for the social cohesion in the Europe. Subsequently, in year 2000, European Commission declared its goal for next decade - 'to become a knowledge economy, increase capabilities for sustainable economic growth, to increase employment opportunities, and achieving greater social cohesion. Accordingly, in year 2001 Green Paper 366 was issued by the European Commission. The Green Paper 366 put emphasis on two key aspects. First, promoting best practices in Corporate Social Responsibility and secondly, development of a European CSR Framework, and to foster social cohesion through the Corporate Social Responsibility initiatives. It brought, apart from internal and external dimensions, a holistic approach towards Corporate Social Responsibility in the Europe. The outcomes after the Green Paper 366 are as under:

- Integrating CSR in all European Commission Policies

- Launching an European Commission's Multi-stakeholders' Forum on CSR

- Promoting convergence and transparency of CSR policies and tools

- Development of a European Action Framework on CSR

(European Union Commission, 2001)

\section{United Nations' Global Compact}

In year 1999, United Nations' Secretary General Mr. Kofi Annan announced the concept that 'Globalisation is promoting the advancement and development of the countries, but there are negative results as well, particularly more widespread poverty and more environmental degradations; and these problems may only be resolved through the collective action of corporations that are active internationally.'Accordingly, in year 2000, United Nations' global Compact was released with 10 principles. These principles were based on the: Universal Deceleration of Human Rights (UDHR); International Labour Organisation's Fundamental Principles and Rights at Workplace; and Principles on Rio Deceleration on Environment and Development. (United Nations Global Compact, 2000)

\section{Global Reporting Initiative}

Global Reporting Initiative is a voluntary organisation established by the Coalition for Environmentally Responsible Economies. The organisation has the mandate to work towards developing and promoting globally applicable guidelines on sustainability-related issues. GRI released the guidelines in year 2000 and further revised in 2002, the revised guidelines encompass not only the environment but economic and social issues as well. The guidelines broadly describe the performance indicators based on various social, economic and environmental parameters. (Global Reporting Initiative, 2011) 


\section{ISO 26000:2010}

ISO 26000:2010 was prepared by the ISO/TMB Working Group on Social Responsibility released in year 2010. It was one of the most comprehensive standards ever developed by ISO and received global attention and acceptance. The ISO 26000 is based on 7 principles, 7 Core subjects or requirements; comprising total 36 identified significant issues or potential area to work by organisation (ISO, 2014). The organisation needs to identify which issues are relevant and significant for them to address in prioritised manner, through its own consideration and through dialogue with stakeholders (Atrey, ISO:26000 - Theory and Practice , 2012).

\section{Theories on CSR:}

There are four key philosophies of Corporate Social Responsibility, viz. Utilitarianism, Libertarianism, New Liberalism and Communitarianism (Taka, n.d.). Theories take their roots from the philosophies emerged out of the then practices or ideas in the sphere of time. There has been classification of main CSR theories and related approaches in further four groups, viz.:

1. Instrumental Theories

2. Political Theories

3. Integrative Theories

4. Ethical Theories

(Garriga \& Dome`nec Mele, 2004)

Each CSR Theory presents four dimensions - profits, political performance, social demands and ethical values. CSR Theories and related approaches are focused on one of the following aspects of social reality:

- Economics - adaptation to the environment (related to resources and economics)

- Politics - Goal attainment (related to politics)

- Social Integration - Social Integration

- Ethics - Pattern maintenance or latency (related to cultures and values)

Hence, the classification of the CSR theories has been done based on the above.

\section{Instrumental Theories}

According to the Instrumental theories, Corporation is an instrument for wealth creation and this is its sole social responsibility. Under this theory focus remains on achieving economic objectives through social activities. Table 1.1 shows the approaches under this theory (Table $1.1)$ : 
International Journal of Social Science and Economic Research

ISSN: $2455-8834$

Volume: 05, Issue: 07 "July 2020"

Table 1.1: Approaches of Instrumental Theories

\begin{tabular}{|l|l|}
\hline Approaches & Description \\
\hline $\begin{array}{l}\text { Maximisation of } \\
\text { Shareholders' Value }\end{array}$ & Long-term value maximisation \\
\hline $\begin{array}{l}\text { Strategies for Competitive } \\
\text { Advantages }\end{array}$ & $\begin{array}{l}\text { - Social investments in a competitive context } \\
\text { - Strategies based on the natural resource view of the } \\
\text { firm and the dynamic capabilities of the firm }\end{array}$ \\
\hline Cause-related Marketing & \begin{tabular}{l} 
Strategies for the bottom of the economic pyramid \\
Altruistic activities socially recognised used as an \\
\hline
\end{tabular} \\
\hline
\end{tabular}

\section{Political Theories}

Under Political theories of CSR, it is expected from Corporations to accept social duties and rights to participate in certain social cooperation. Focus of the corporate remains on a responsible use of business power in the political arena. Approaches under this theory are shown in Table 1.2:

Table 1.2: Approaches of Political Theories

\section{Approaches}

Corporate Constitutionalism

\section{Integrative Social Contract}

Theory

Corporate (or Business)

Citizenship

\section{Description}

Social responsibilities of business arise from the amount of social power that they have

Assumes that a social contract between business and society exists

The firm is understood as being like a citizen with certain involvement in the community 


\section{Integrative Theories}

Under the Integrative theories, businesses depend on society for their continuity, growth and existence. Under these theories, focus of corporations remains on the integration of social demands (Table 1.3).

Table 1.3: Approaches of Integrative Theories

\section{Approaches \\ Description \\ Issues Management \\ Corporate processes of response to those social and political issues which may impact significantly upon it \\ Public Responsibility \\ Law and existing Public Policy process are taken as a reference for Social Performance \\ Stakeholder \\ Balances the interests of the stakeholders of the firm \\ Management \\ Corporate Social \\ Searches for Social legitimacy and processes to give appropriate \\ Performance responses to social issues \\ Ethical Theories \\ According to the Ethical theories, relationship between Business and Society is embedded with ethical values. Vision of CSR is viewed from ethical perspectives and focus remains on the right thing to achieve the goals of a fair society (Table 1.4).}

Table 1.4: Approaches of Ethical Theories

\section{Approaches}

Stakeholder

Normative Theory

\section{Description}

Consider fiduciary duties towards stakeholders of the firm. Its application requires reference to some moral theory (Kantian, Utilitarianism, Theories of Justice, etc.) 
Universal Rights

Sustainable

Development

The Common Good
Frameworks based on human rights, labour rights and respect for the environment

Aimed at achieving human development considering present and future generations

Oriented towards the common good of the society

Most of current CSR Theories are focused on:

- Meeting objectives that produce long-term profits

- Using business power in a responsible way

- Integrating social demand

- Contributing to a good society by doing what is ethically correct

Accordingly, classification of theories in four groups has been done, namely Instrumental, Political, Integrative, and Ethical. There is necessity to develop a new theory on the business and society relationship. It is, however, challenging to develop a new theorywhich will require an accurate knowledge of reality and a sound ethical foundation and will overcome the persistent limitations in the present theories.

\section{CSR Models:}

\section{Carrol's Model on CSR}

Carroll presented first model in 1991 termed as the Carroll's Pyramid Model in which various responsibilities of business, viz. Economic, Legal, Ethical and Philanthropic were kept in form of a pyramid denoting to their specific expectations by society and actions required by business (Figure 1.1). 


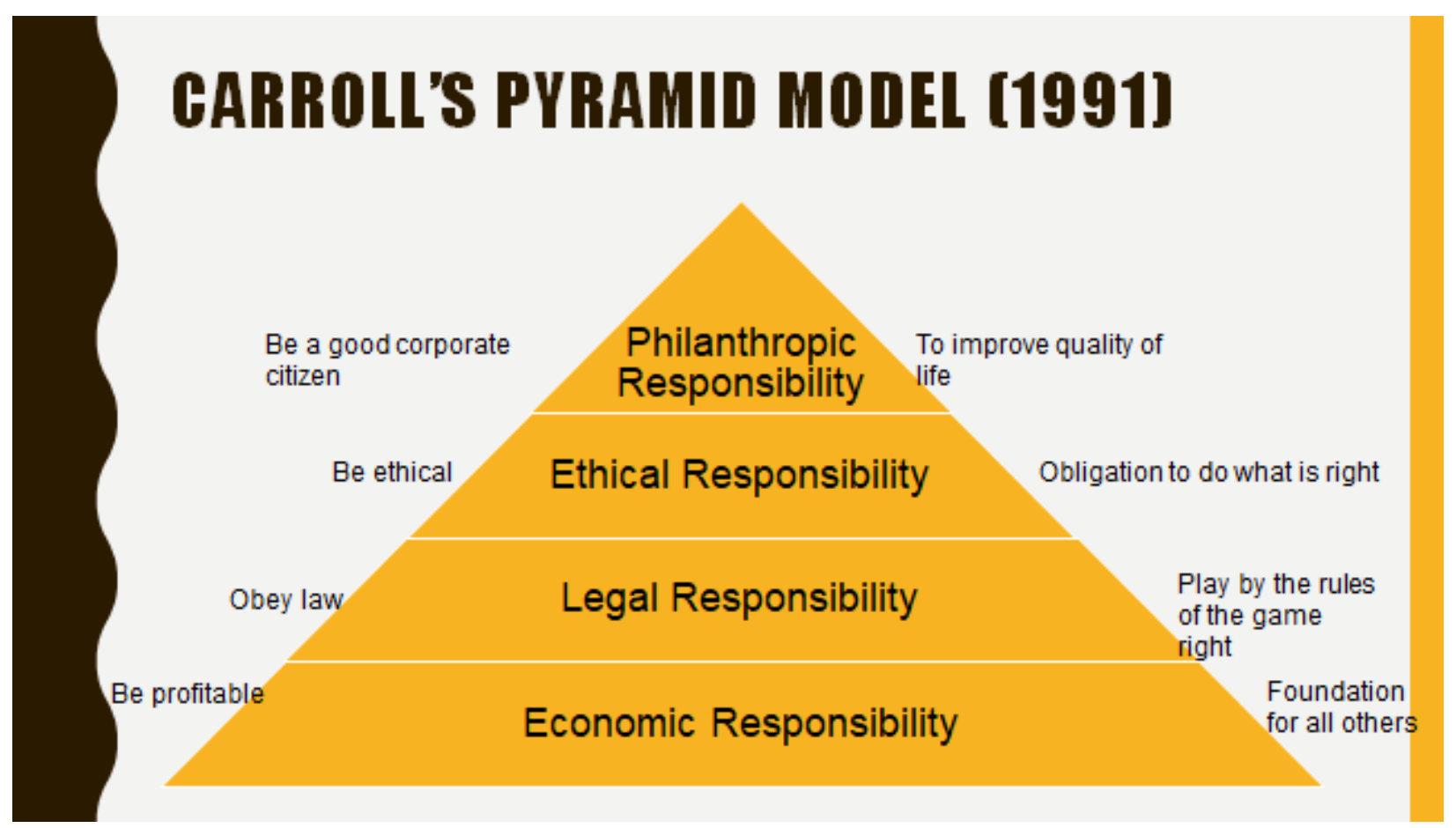

\section{Figure 1.1: Carroll's Pyramid Model}

He kept the economic responsibility at the core of the pyramid with the view that profit making is the core responsibility for a business to survive and it is foundation for all other responsibilities. Legal, Ethical and Philanthropic responsibilities of the business were kept respectively in an order of less importance after economic responsibility (Figure 1.2). 


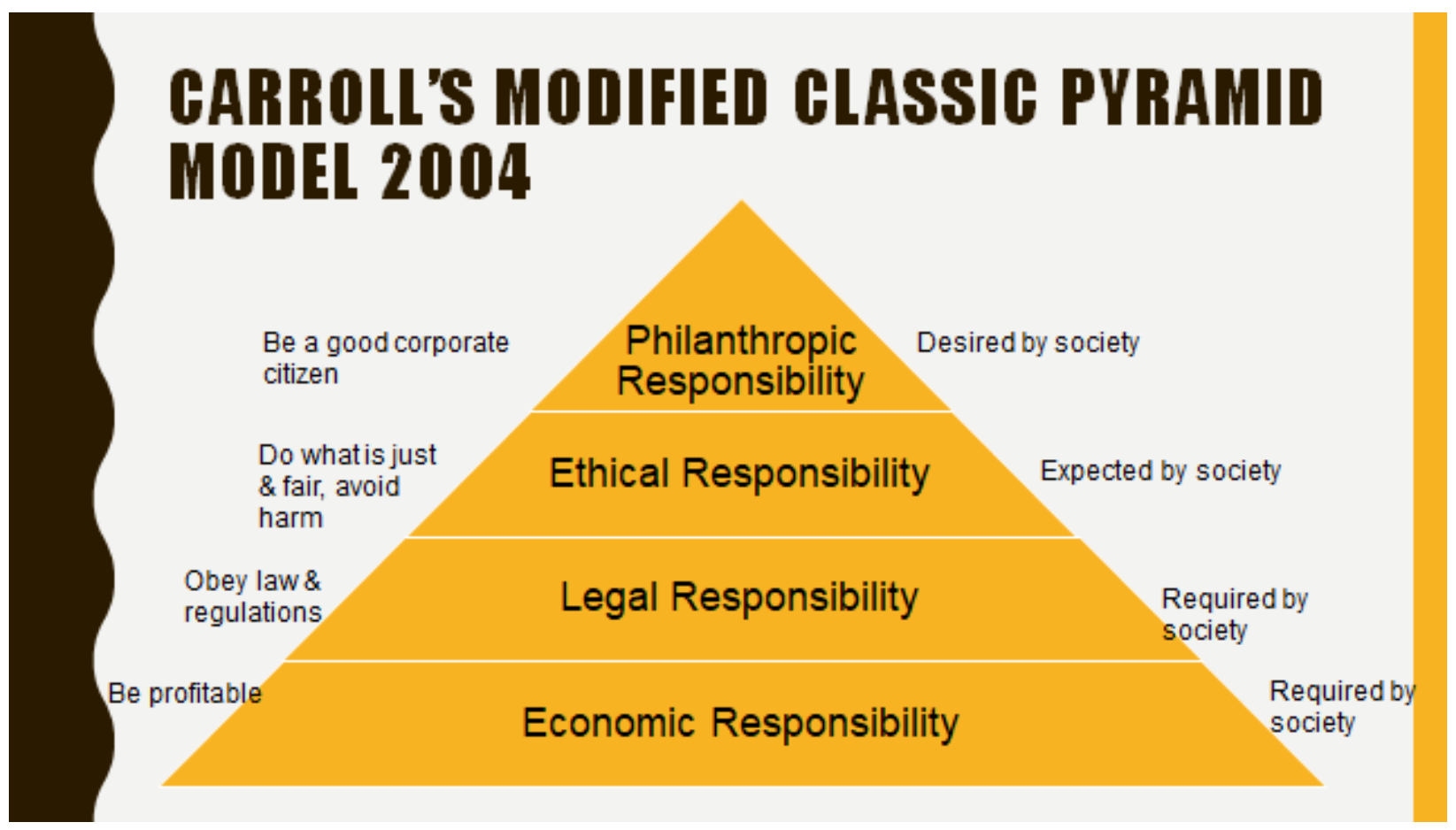

Figure 1.2: Carroll's Modified Classic Pyramid Model

Carroll again revisited his model and made some changes in the model description. For economic responsibility he changed the term 'Foundation for all other responsibilities' to 'required by the society'. With respect to legal responsibility the term 'play by the rules of game right' was changed again with 'required by the society'. In the ethical responsibility, narration 'obligation to do what is right' was changed with 'expected by society'. In the Philanthropic responsibility, 'to improve quality of life' was replaced with 'desired by the society'. He also described the term 'be ethical' as 'do what is just and fair; avoid harm'. You may also compare above two diagrams of Carroll's CSR Model for more specific view.

\section{Visser's Pyramid Model}

Visser's Pyramid Model of CSR was also based on arranging various responsibilities of business in priority order where economic responsibility was highest priority and ethical responsibility was of lowest (Figure 1.3). 


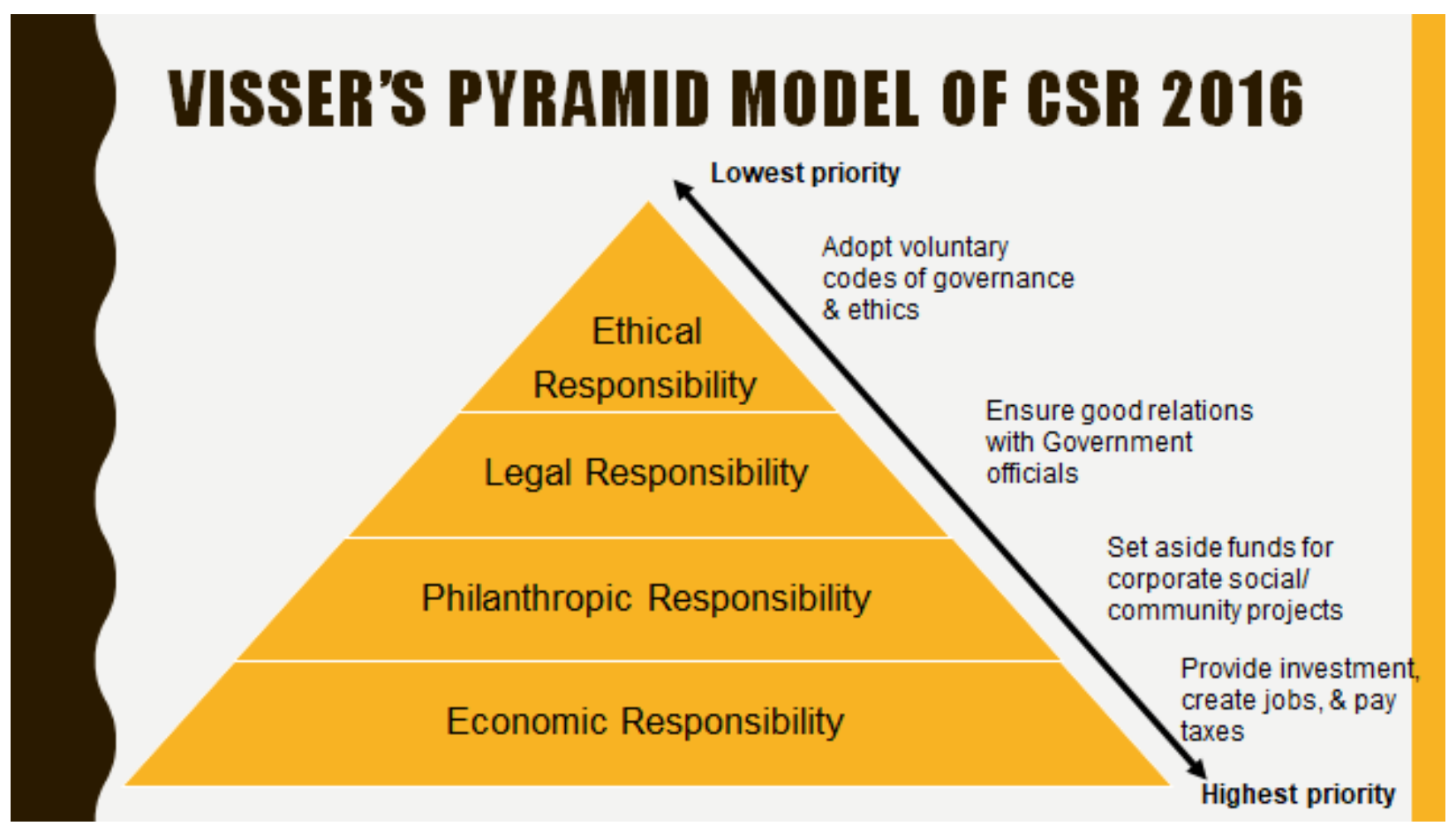

Figure 1.3: Visser's Pyramid Model of CSR

The major change observed in Visser's model was change of order of responsibilities from Carroll's model. Philanthropic responsibility in Visser's model was kept just next to economic responsibility of the business.

\section{International Pyramid Model}

International Pyramid Model of CSR was also based on prioritisation of various responsibilities of business. Again in this model the philanthropic responsibility was kept as lowest priority for business. (Masoud, 2017) 


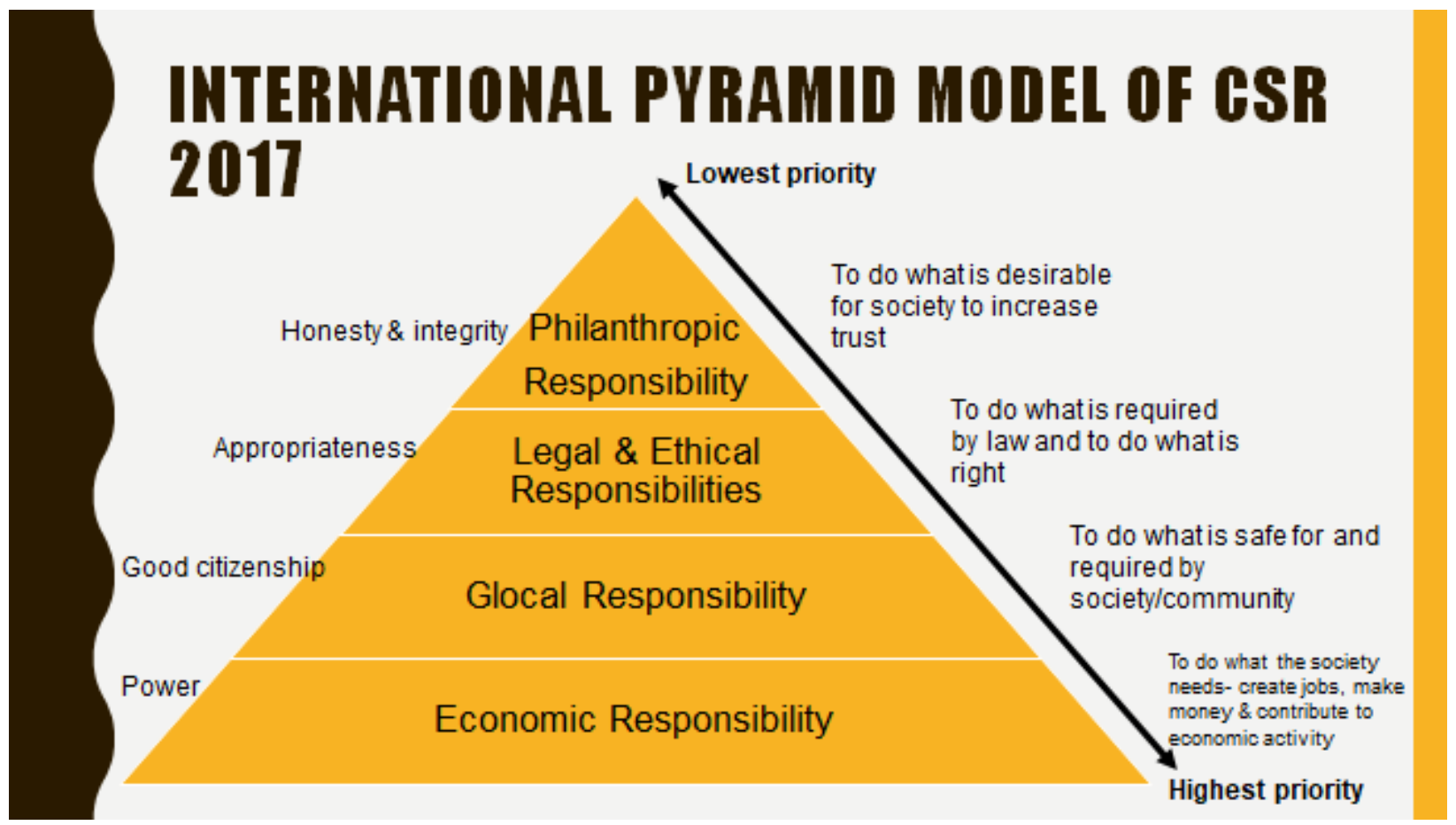

Figure 1.4: International Pyramid Model

Description of expectations and obligations of the businesses have been slightly different in this model from the earlier ones. A new layer of global responsibilities was added in the model (Figure 1.4)

\section{Analysis of Existing CSR Models}

Table 1.5: Comparison of Carroll's Model, Visser's Model and International Model

\begin{tabular}{|l|l|l|l|}
\hline & Carroll's Model & Visser's Model & International Model \\
\hline & $\begin{array}{l}\text { Established Modern } \\
\text { CSR Concept }\end{array}$ & $\begin{array}{l}\text { Focus on developing } \\
\text { countries }\end{array}$ & $\begin{array}{l}\text { Glocal drivers of CSR } \\
\text { - Power structure in society } \\
\end{array}$ \\
& & $\begin{array}{l}\text { Legal and ethical } \\
\text { responsibilities as drivers of } \\
\text { CSR }\end{array}$ \\
\hline
\end{tabular}




\begin{tabular}{|c|c|c|c|}
\hline 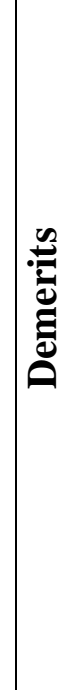 & $\begin{array}{l}\text { - Generated within the } \\
\text { United States of } \\
\text { America } \\
\text { - Global applicability } \\
\text { is challengeable } \\
\text { - How different } \\
\text { responsibility } \\
\text { interact and } \\
\text { influence each-other } \\
\text { - Does not address } \\
\text { Cultural obligation }\end{array}$ & $\begin{array}{l}\text { - Tested in African } \\
\text { countries } \\
\text { - Less pressure of good } \\
\text { conduct } \\
\text { - More emphasis on } \\
\text { economic } \\
\text { responsibilities and } \\
\text { profit motives } \\
\text { - No practical guidance } \\
\text { for companies to } \\
\text { implement CSR }\end{array}$ & $\begin{array}{l}\text { - No comparative empirical } \\
\text { study has been conducted. } \\
\text { - Order of layers may differ in } \\
\text { different regions } \\
\text { - More emphasis on economic } \\
\text { responsibility } \\
\text { - Corporate competitive context } \\
\text { - focus not on society's } \\
\text { problems but on profits }\end{array}$ \\
\hline
\end{tabular}

\section{Way ahead:}

Based on the analysis of the international and national circumstances, legal and guiding instruments and business trends in India and their orientation towards Corporate Social Responsibility, it has been observed that the prime objective of the business has been to make profits by exploiting the natural and human resources. It has further been observed that such practices have caused crisis that we have been facing presently and are endangered to our future generations. In light of this, Corporate Social Responsibility is to be seen, studied and practiced in India specific circumstances, Corporate Social Responsibility is an important function for the business community to establish themselves as well-wishers in the social development and in preventing/reducing natural and environmental crisis. CSR mechanism is a beginning towards integrating the responsible business behaviours towards society, environment and planet while making profits. Accordingly, based on the analysis of different aspects in this paper, a new model on Corporate Social Responsibility has been proposed as under:

\section{Atrey's Tree Model of CSR (A New Model of CSR in India)}

It has been observed that the literature in CSR presents models developed in the west. The author realised that it is necessary in the present context in India to study and adopt an indigenous model of CSR. Given the Indian origin, this model will also be applicable in any country because of its universal nature. This model (Figure 1.5) can be termed as 'Atrey's Tree Model of CSR'. 


\section{International Journal of Social Science and Economic Research}

ISSN: 2455-8834

Volume: 05, Issue: 07 "July 2020"

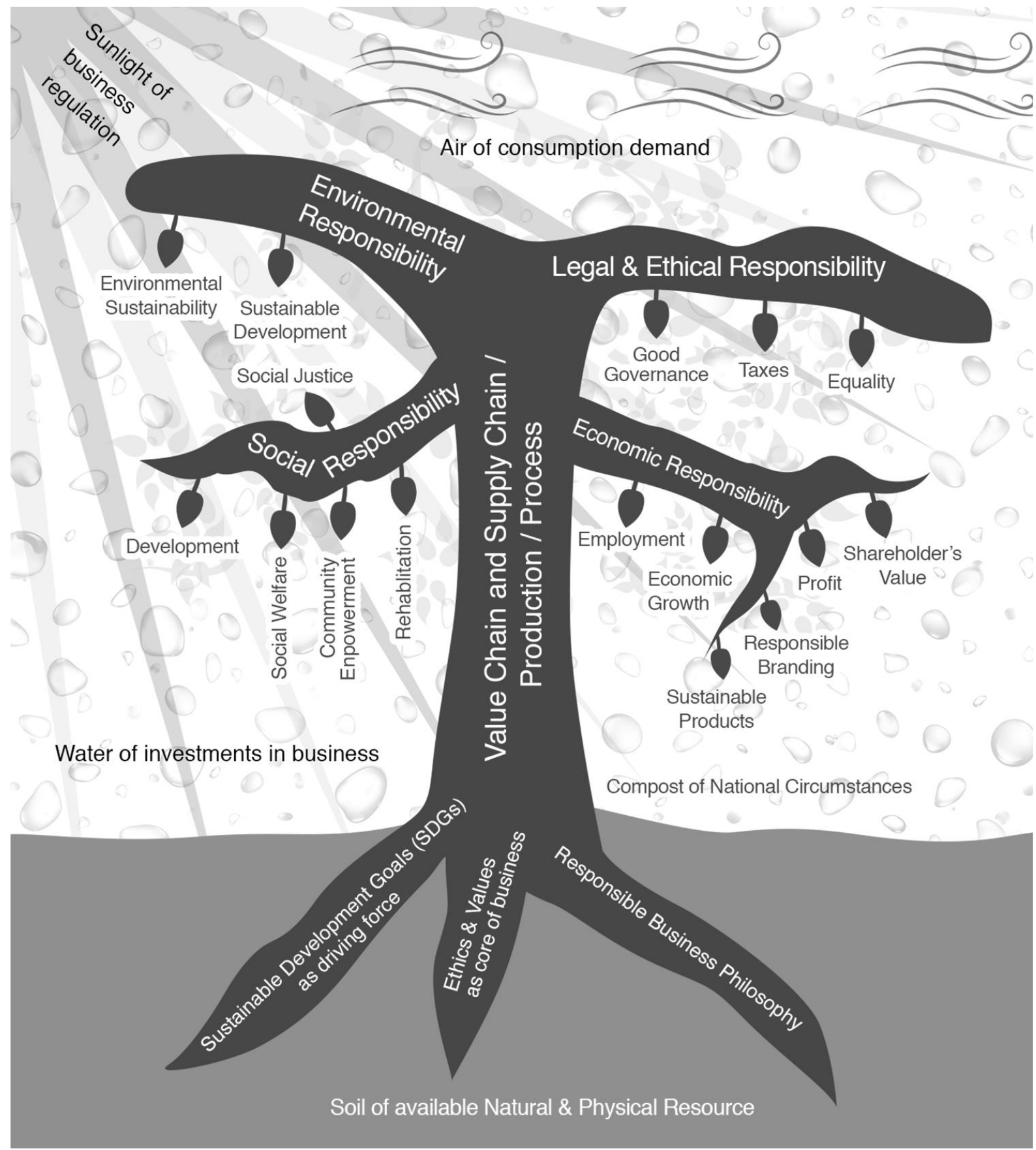

Figure 1.5: Atrey's Tree Model of CSR

(Atrey, Exploring Corporate Social Responsibility - Fundamentals and Implementation Ed. II, 2020) 
Soil

- Available Natural and Physical Resources

Resources needed to grow

- Compost of National Circumstances

- Water of Investments in Business

- Sunlight of Business Regulations

- Air of Consumption Demand

Roots

- Ethics and Values as Core of Business

- Sustainable Development Goals (SDGs) as Driving Force

- Responsible Business Philosophy

Timber of the tree

- Value Chain and Supply Chain

- Manufacturing or Service delivery processes

Branches

- Economic Responsibility

- Legal and Ethical Responsibility

- Social Responsibility

- Environmental Responsibility

Fruits in the form of

- Economic Sustainability

- Profit

- Economic Growth

- Shareholders' Value

- Sustainable Products

- Responsible Branding

- Employment Creation

- Good Governance

- Contribution to Taxes

- Equality 
- Social Sustainability

- Social Justice

- Social Development

- Social Welfare

- Community Empowerment

- Rehabilitation

- Environmental Sustainability

- Sustainable Development

\section{Seed}

- Corporate Social Revolution

\section{Key Characteristics of the Model}

- Ethical and value driven model

- Responsible behaviour at each step of business activity

- No emphasis on more or less importance of different layers (all layers / aspects of business are equally important)

- Indian context is taken care as well

- Applicability to other countries irrespective of nature

- Aligns CSR with SDG

- Initiates Corporate Social Revaluation

\section{Model Description}

The tree will grow in the soil of available resources in terms of natural and physical. As there is scarcity of resources, a revolutionary action was required to secure a sustainable future. The seed to be grown will be termed as the seed of corporate social revolution. The word social for the purpose of seed comprise economic, environmental and social wellbeing as all these leads towards a sustainable future for our next generations thereby forming future structure of societies.

Required resources necessary to the growth of tree will be water in the form of investments in businesses. As the global trend for investment has been towards sustainable businesses, if an ecosystem of sustainability will be provided, it could attract more and more investments. Sunlight required for the growth of tree will be various business regulations from government. More complex the business regulations, less will be the reach of sunlight resulting into poor growth of business. The compost will be in the form of national circumstances denoting to the socio- 


\section{International Journal of Social Science and Economic Research}

ISSN: $2455-8834$

Volume: 05, Issue: 07 "July 2020"

cultural practices, governance structures, political economy aspects and many other such aspects. Air required to survive will be consumption demand.

Roots of the tree will be comprised of Ethics and Values. As the ethical behaviour is the core for any kind of sustainability and a prerequisite for businesses for being responsible (socially, economically and environmentally). Responsible Business philosophy will also be a root for business existence. Sustainable Development Goals (SDGs) will work as a driving force for carrying out and alignment of business activities.

Timber of the tree will denote value chain and supply chain of the business based on ethics, sustainable development and responsible behaviour. Manufacturing or service delivery will be processed accordingly.

Branches of the tree will denote various responsibilities of the business in terms of social, economic, environmental, legal and ethical. These were presented as layers of importance for businesses in earlier models of CSR but in present model, these responsibilities will have equal weightage with driving their roots from ethics/values-Sustainable development and responsible behaviour.

Fruits, which the tree will produce, will comprise Economic Sustainability, Profit, Economic Growth, Shareholders' Value, Sustainable Products, Responsible Branding, Employment Creation, Good Governance, Contribution to Taxes, Equality, Social Sustainability, Social Justice, Social Development, Social Welfare, Community Empowerment, Rehabilitation, Environmental Sustainability, and Sustainable Development.

Seed has been attributed as corporate social revolution. As clarified earlier, seed will comprise economic, environmental and social wellbeing/sustainability. It has been termed as corporate social revolution because when the fruits will grow and will be utilised, these will leave sustainable footprints for future generations. Each seed will grow again in its respective sphere and will become a responsible business tree, thereby contributing to a corporate social revolution.

\section{BIBLIOGRAPHY}

(2015). AA1000 Stakeholder Engagement Standard. Account Ability.

Atrey, R. R. (2020). Exploring Corporate Social Responsibility- Fundamentals and Implementation Ed. II. New Delhi: Studera Press.

Atrey, R. R. (2012). ISO:26000 - Theory and Practice . In S. Mittal, CSR and Competitiveness. Allied Publishers. 
International Journal of Social Science and Economic Research

ISSN: $2455-8834$

Volume: 05, Issue: 07 "July 2020"

cauxroundtable.org. (2010). Caux Round Table Principles for Responsible Business. http://www. cauxroundtable.org/index.cfm?menuid=8 .

European Union Commission. (2001). Green Paper: Promoting a European Framework for Corporate Social Responsibility. Commission of the European Communities, Doc/01/9, 2001.

Garriga, E., \& Dome`nec Mele. (2004). Corporate Social Responsibility Theories: Mapping the Territory. Journal of Business Ethics , 51-71.

Global Reporting Initiative. (2011). Global Reporting Initiative, Report Template.

ISO. (2014). Basic Training Material on ISO 26000, Social Responsibility. ISO 26000 PPO N 48.

Masoud, N. (2017). How to win the battle of ideas in corporate social responsibility: the International Pyramid Model of CSR. International Journal of Corporate Social Responsibility .

Ministry of Corporate Affairs, Government of India. (2011). National Voluntary Guidelines on Social, Environmental and Economic Responsibilities of Business.

Ministry of Corporate Affairs, Govt. of India. (2016). CSR Expenditure Trends .

Ministry of Corporate Affairs, Govt. of India. (2018). National Guidelines on Responsible Business Conduct.

Ministry of Corporate Affairs, Govt. of India. (2019). Report of the High Level Committee on Corporate Social Responsibility 2018.

Ministry of Corporate Affairs, Govt. of India. (2018). Scheme for National CSR Awards.

Organization for Economic Cooperation and Development. (2008). OECD Guidelines for Multinational Enterprises.

Rai, S., \& Bansal, S. (n.d.). An analysis of Corporate Social Responsibility Expemditure in India. Economic \& Political Weekly.

Reitaku University Business Ethiics and Compliance Research Centre. (2007). CSR Accounting Guidelines.

Social Accountability International. (2001). Social AccountAbility 8000, International Standard. Social Accountability International. 
International Journal of Social Science and Economic Research

ISSN: $2455-8834$

Volume: 05, Issue: 07 "July 2020"

Taka, I. (n.d.). Four Social Philosophies and Corporate Social Responsibility Approaches and Issues for Companies. NIKKEI CSR Project.

(1999). The Millennium Poll on Corporate Social Responsibility, Global Public Opinion on the Changing Role of Companies. Environics International Ltd.

United Nations Global Compact. (2000). The Ten principles of UN Global Compact. https://www. unglobalcompact.org/what-is-gc/mission/principles .

Visser, W. (2011). The Age of Responsibility, CSR 2.0 and the New DNA of Business. Wiley, a John Wiley \& Sons Ltd. Publication. 